
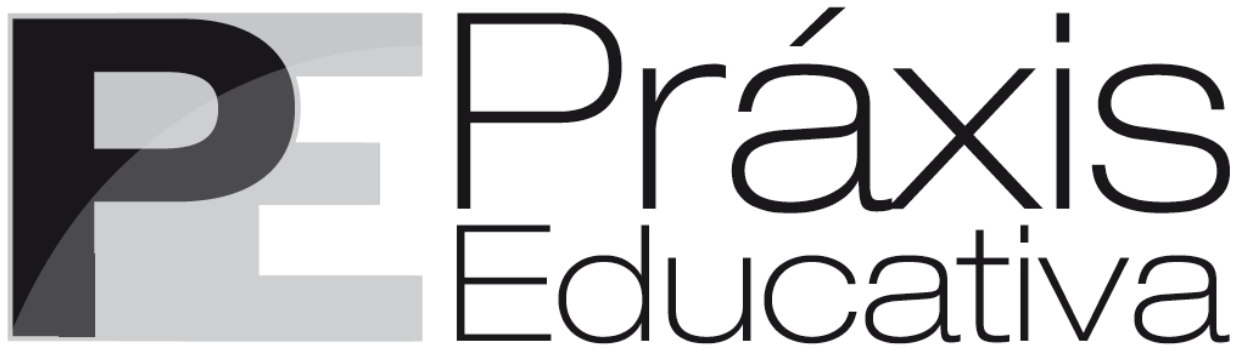

ISSN 1809-4031

elSSN 1809-4309

https://doi.org/10.5212/PraxEduc.v.15.17067.101

\title{
A epistemologia de Paulo Freire na formação de pedagogas(os) durante os Estágios Curriculares Supervisionados
}

\section{Paulo Freire's epistemology in pedagogues education during Supervised Curricular Internships}

\section{La epistemología de Paulo Freire en la formación de pedagogas(os) durante las Pasantías Curriculares Supervisadas}

\author{
Lucimara Cristina de Paula* \\ https://orcid.org/0000-0002-9556-7960
}

\begin{abstract}
Resumo: Este artigo apresenta parte de uma pesquisa que objetivou investigar nas construções teóricas e nas ações dialógicas do "método de alfabetização" de Paulo Freire contribuições para a organização didática dos Estágios Curriculares Supervisionados no curso de Pedagogia, bem como sistematizar orientações teóricas e práticas para os estágios em uma perspectiva problematizadora a partir da práxis desse pensador. Trata-se de uma pesquisa bibliográfica em relação às construções teóricas de Freire sobre sua educação problematizadora. A partir das concepções de ser humano, educação e realidade, que oferecem bases para a educação problematizadora de Paulo Freire, foram sistematizadas orientações para o planejamento e a prática docente nos estágios, fundamentadas na pesquisa rigorosa, na curiosidade epistemológica, na dialogicidade, na solidariedade, na criticidade, na leitura de mundo, na humildade, na ética, na estética e no compromisso político com a aprendizagem de todos e todas.
\end{abstract}

Palavras-chave: Estágio Curricular Supervisionado. Curso de Pedagogia. Paulo Freire.

\begin{abstract}
This article presents part of a research that aimed to investigate in the theoretical constructions and dialogical actions of Paulo Freire's "literacy method" contributions to the didactic organization of Curricular Supervised Internships in the Pedagogy course, as well as to systematize theoretical and practical guidelines for internships in a problematizing perspective based on the praxis of that thinker. This is a bibliographic research in relation to Freire's theoretical constructions about his problematizing education. From the conceptions of human being, education and reality, which provide bases for Paulo Freire's problematizing education, guidelines for planning and teaching practice were systematized in internships, based on rigorous research, epistemological curiosity, dialogicity, solidarity, criticality, reading the world, humility, ethics, aesthetics and political commitment to the learning of all.
\end{abstract}

Keywords: Supervised Curricular Internship. Pedagogy course. Paulo Freire.

\footnotetext{
* Doutora em Educação. Professora Adjunta do Departamento de Pedagogia e docente do Programa de PósGraduação em Educação da Universidade Estadual de Ponta Grossa (UEPG), Paraná. Coordenadora do Grupo de Estudos e Pesquisas sobre Educação em Espaços Escolares e Não Escolares (GEPEDUC). E-mail: $<$ lucrispaula@gmail.com>.
} 
A epistemologia de Paulo Freire na formação de pedagogas(os) durante os Estágios Curriculares...

Resumen: Este artículo presenta parte de una pesquisa que tuvo por objetivo investigar en las construcciones teóricas y en las acciones dialógicas del "método de alfabetización" de Paulo Freire contribuciones para la organización didáctica de las Pasantías Curriculares Supervisadas en el curso de Pedagogía, bien como sistematizar orientaciones teóricas y prácticas para las pasantías en una perspectiva problematizadora a partir de la praxis de este pensador. Se trata de una investigación bibliográfica en relación a las construcciones teóricas de Freire sobre su educación problematizadora. A partir de las concepciones de ser humano, educación y realidad, que ofrecen bases para la educación problematizadora de Paulo Freire, fueron sistematizadas orientaciones para el planeamiento y la práctica docente en las pasantías fundamentadas en la investigación rigurosa, en la curiosidad epistemológica, en la dialogicidad, en la solidaridad, en la criticidad, en la lectura de mundo, en la humildad, en la ética, en la estética y en el compromiso político con el aprendizaje de todos y todas.

Palabras-clave: Pasantía Curricular Supervisada. Curso de Pedagogía. Paulo Freire.

\section{Introdução}

O Brasil é um dos países mais desiguais do mundo, segundo dados do Banco Mundial (BRANDÃO, 2018). Os 5\% mais ricos da população têm a mesma renda mensal que os 95\% juntos, e mais de 16 milhões de pessoas viviam abaixo da linha da pobreza no Brasil em 2017. Tal situação de desigualdade se torna mais evidente e aprofundada no contexto de uma pandemia de proporções mundiais, causada pelo novo coronavírus (COVID-19), que avança de forma assustadora em números de contaminados e mortos no Brasil, especialmente entre a população mais pobre, desde o dia 30 de janeiro de 2020, quando a Organização Mundial de Saúde ${ }^{1}$ (OMS) declarou que o surto da doença causada pelo novo coronavírus (COVID-19) constituía uma Emergência de Saúde Pública de Importância Internacional, o mais alto nível de alerta da OMS, conforme o Regulamento Sanitário Internacional (OPAS, 2020).

Diante dos dados, torna-se impossível discutir a formação de professoras e professores sem fazer destaque a esse contexto perverso e complexo que vem se desenhando historicamente e se agrava pela intensificação de políticas ultraconservadoras e neoliberais que retiram direitos dos(as) trabalhadores(as), ameaçam os direitos humanos, atacam a democracia, provocam o desmonte dos sistemas públicos de ensino e do Sistema Único de Saúde (SUS), banalizam a imensa mortandade de pessoas vitimadas pela pandemia, privilegiam os interesses de mercado em detrimento do controle da doença e investimento no combate a ela, enquanto negligenciam repasse de recursos à pesquisa, principalmente na área das Ciências Humanas.

A formação de professoras e professores não pode ser pensada fora desse mundo social, político, econômico, cultural, midiático, tecnológico, em que diversas forças antagônicas estão em jogo e impõem a necessidade de um posicionamento rigorosamente ético de formadores e formadoras, frente às inúmeras formas de desigualdade, injustiça, violência, desumanização sofridas pela população. Refiro-me à ética universal do ser humano defendida por Paulo Freire (2014) e não à ética de mercado, que atende aos interesses do lucro e dissemina formas fatalistas de conceber a condição de uma maioria de pessoas subtraídas de seus direitos, enquanto se propaga a naturalização dos direitos e dos privilégios de uma minoria.

Dentro desse contexto, a escola que conhecemos hoje ainda conserva características adquiridas a partir da revolução industrial, com a função de formar as novas gerações para o mundo do trabalho e para um modelo de organização urbana, como se fosse fonte exclusiva de difusão do conhecimento e tendo os professores e as professoras como seus transmissores (MELLO; BRAGA; GABASSA, 2012). Essa organização escolar tem demonstrado inoperância, denunciada pelos baixos índices de aprendizagem expressos nas avaliações, conforme dados da Avaliação

${ }^{1}$ Disponível no site < https://www.paho.org>.

Práxis Educativa, Ponta Grossa, v. 15, e2017067, p. 1-23, 2020

Disponível em: < https://www.revistas2.uepg.br/index.php/praxiseducativa> 
Nacional da Avaliação (ANA) de 2016, que apontaram o índice de 55\% de alunos com oito anos de idade que não se encontravam plenamente alfabetizados (BRASIL, 2018).

A essas perspectivas nada otimistas, somam-se medidas legais voltadas à Educação Básica e à formação de professores profundamente alinhadas aos interesses dos detentores do capital, apoiadores dos poderes estaduais e federais de linha extremamente conservadora. No que tange à formação de professores, constatamos a promulgação da Resolução CNE/CP No 2, de 20 de dezembro de 2019, que define as Diretrizes Curriculares Nacionais para a Formação de Professores para a Educação Básica e institui a Base Nacional Comum para a Formação Inicial de Professores da Educação Básica (BRASIL, 2019). Ao manifestar retrocesso em relação às Diretrizes Curriculares Nacionais (DCN) para a formação inicial em nível superior e para a formação continuada de 2015 (Resolução N $^{\circ}$ 2, de $1^{\circ}$ de julho de 2015), e ignorar a posição das entidades da área, as novas diretrizes mostram, ainda, um teor prescritivo e neoliberal, praticista e tecnicista, desconsiderando questões importantes como a carreira docente e a criação de um órgão regulador da formação (FREITAS, 2020).

\footnotetext{
Com as novas determinações, ficou escancarada a abertura do "mercado educacional" da formação para que, além das universidades privadas de caráter mercantilista que hoje dominam o campo educacional e são responsáveis por aproximadamente $80 \%$ das vagas de licenciaturas e a maioria [a] distância, as fundações educacionais do segmento empresarial e outras organizações sociais possam oferecer cursos de nível superior, sem quaisquer dos requisitos necessários exigidos das Universidades, como carreira, formação e pesquisa cientifica. (FREITAS, 2020, p. 2).
}

A relação entre o contexto social nacional, a organização escolar de vertente autoritária, a urgência de ensino de qualidade, as políticas conservadoras para a formação de professores colocam-nos desafios para os estágios curriculares nos cursos de Pedagogia, que não podem ser ignorados, se desejamos construir um currículo formativo que envolva as dimensões política, ética, humana, técnica e cultural de forma equilibrada, com vistas à diversidade de necessidades e à inclusão de todos os alunos e alunas (GATTI et al., 2019). Por representar um momento especial da formação inicial, em que os/as estudantes têm a possibilidade de atuar em colaboração, repensar teorias, pesquisar, constituir saberes, estabelecer relações, criar soluções para problemas, avaliar sua opção profissional, o estágio curricular constitui um momento especial da formação, que pode aproximar universidade-escola, contribuindo para a ampliação de conhecimentos de ambas (GABRIEL; PEREIRA; JESUZ, 2018).

A experiência como orientadora de Estágios Curriculares Supervisionados em docência nos anos iniciais do Ensino Fundamental do curso de Pedagogia, desenvolvendo relações de orientação, planejamento e acompanhamento das regências de classe, tem me mostrado que essa etapa da formação é impactante para as futuras professoras e os futuros professores, como momento de descobertas, de estranhamentos e de construção de conhecimentos. Entretanto, é também, oportunidade de enxergar-se como sujeitos políticos e éticos, que têm responsabilidades sociais e tomam decisões importantes em relação ao próprio trabalho.

Comprometida com a formação ética, política, crítica e humanizadora das futuras professoras e dos futuros professores, desenvolvi a pesquisa intitulada Em busca de uma formação problematizadora e crítica durante os Estágios Curriculares Supervisionados: perspectivas a partir da práxis freiriana (2017-2020), cujos resultados, colocados em prática com duas turmas, apontam desafios, limites e possibilidades.

$\mathrm{Na}$ sequência, apresento parte de uma revisão bibliográfica das pesquisas que tratam sobre o estágio nos cursos de Pedagogia, levantadas no Catálogo de Teses e Dissertações da Coordenação 
A epistemologia de Paulo Freire na formação de pedagogas(os) durante os Estágios Curriculares...

de Aperfeiçoamento de Pessoal de Nível Superior - Capes (2000-2019), e, posteriormente, apresento minha pesquisa, fundamentada na epistemologia de Paulo Freire.

\section{Revisão das pesquisas sobre o Estágio Curricular Supervisionado no curso de Pedagogia}

A delimitação, a definição e a formulação do problema que mobilizou a pesquisa expressa neste texto surge a partir de meu envolvimento direto com a disciplina de Estágio Curricular Supervisionado em Docência nos anos iniciais do Ensino Fundamental, desenvolvido com as turmas de $4^{\circ}$ ano do curso de Pedagogia da Universidade Estadual de Ponta Grossa (UEPG). O trabalho teórico-prático que envolve discussão de concepções teóricas, orientação dos(as) estudantes para as ações de observação, planejamento e realização de docências, acompanhamento dos(as) estudantes nas escolas, mediação entre equipe escolar e estagiários(as), processos avaliativos e autoavaliativos, exige posicionamento político por parte da professora orientadora dos estágios, atualização profissional permanente e diálogo constante para a resolução de problemas e a minimização de conflitos, de inseguranças, de ansiedades e de medos. Esse processo de trabalho coloca o desafio permanente de refazer a própria atuação a cada ano, a cada aprendizado com uma nova turma, a cada erro, a cada relação humana estabelecida e, consequentemente, exige a construção de novos rumos para o trabalho complexo desenvolvido como professora e orientadora dos estágios.

Esse desafio provocou a busca por uma práxis docente orientada por princípios epistemológicos que correspondessem a uma formação mais crítica, ética, estética, humanista e indagadora dos(as) professores(as) em formação. Os princípios para uma formação dessa natureza foram encontrados na pedagogia problematizadora de Paulo Freire, considerado o principal pedagogo da atual sociedade da informação, devido ao giro dialógico das ciências sociais atuais, orientadas em direção às contribuições de Freire e ao compromisso proposto pelo autor em sua Pedagogia do oprimido (FLECHA, 2001).

Os movimentos sociais igualitários e a intelectualidade crítica foram abrindo espaço para
uma alternativa progressista: uma sociedade da informação para todas as pessoas. Paulo
Freire desempenhou um papel-chave no surgimento dessa alternativa, proclamando que
a questão estava em "transformar as dificuldades em possibilidades" e escrevendo que
"uma das tarefas mais importantes para os intelectuais progressistas é desmistificar os
discursos pós-modernos sobre a inexorabilidade desta situação". (FLECHA, 2001, p.
204).

Considerando os desafios postos ao próprio trabalho e o compromisso com uma formação docente comprometida com a diminuição das desigualdades sociais, das injustiças, da segregação de grupos sociais e culturais que adentram as escolas da Educação Básica, realizei uma busca por pesquisas pautadas nos princípios da pedagogia progressista de Paulo Freire, na intenção de encontrar contribuições para o trabalho realizado com os Estágios Curriculares Supervisionados nos cursos de Pedagogia.

Nesse sentido, a fim de verificar o que revelam as produções científicas sobre o Estágio Curricular Supervisionado nos cursos de Pedagogia, publicadas nos últimos 20 anos (2000 a 2019) na plataforma SciELO (www.scielo.org) e no Catálogo de Teses e Dissertações da Capes (www.catalogodeteses.capes.gov.br), realizei um levantamento bibliográfico das produções científicas (artigos, dissertações e teses) por meio das palavras-chave: Estágio, Estágio curricular supervisionado, Estágio curricular, Estágio supervisionado - para a busca de teses e dissertações; e Estágio AND Pedagogia - para a busca de artigos. Devido à impossibilidade de discutir todos os dados neste texto, optei pela discussão dos dados referentes ao Catálogo de Teses e Dissertações da Capes.

Práxis Educativa, Ponta Grossa, v. 15, e2017067, p. 1-23, 2020 Disponível em: < https://www.revistas2.uepg.br/index.php/praxiseducativa> 
Esse levantamento bibliográfico objetivou mapear as pesquisas de Mestrado e de Doutorado acadêmicos para identificar seus temas, seus problemas, seus objetivos, suas metodologias, seus referenciais teóricos e principais resultados. A revisão da literatura colabora para determinar se vale a pena estudar o tema e oferece elementos para delimitação dele, a partir dos resultados de outros estudos, estabelecendo o diálogo maior da literatura com o tema proposto para preenchimento de lacunas. Ao mesmo tempo, a revisão da literatura permite evidenciar a importância do estudo e oferece referências para comparar resultados com outros resultados (CRESWELL, 2010) Esse tipo de estudo é necessário ao processo de evolução da ciência, na medida em que permite ordenar periodicamente o conjunto de informações e resultados já obtidos, favorecendo a integração e a configuração emergentes, as diferentes perspectivas investigadas, os estudos recorrentes, as contradições encontradas (VOSGERAU; ROMANOWSKI, 2014).

Para este artigo, decidi pela apresentação e análise dos temas referentes às teses e às dissertações, a partir da leitura de seus objetos de estudo e seus objetivos, verificando também em quantas produções encontramos as contribuições de Paulo Freire e se há produções que são fundamentadas na pedagogia progressista do autor, em relação aos Estágios Curriculares Supervisionados nos cursos de Pedagogia. Portanto, as informações apresentadas sobre a revisão não serão abrangentes nesse momento, pois as análises estão sendo aprofundadas em nova pesquisa do tipo estado do conhecimento.

O acesso ao Catálogo de Teses e Dissertações da Capes permitiu a coleta de 1.233 teses e dissertações com a palavra-chave Estágio, 124 produções com a utilização da palavra-chave Estágio Curricular Supervisionado; 216 produções com a palavra-chave Estágio Curricular e 423 produções com a palavra-chave estágio supervisionado. Essas quatro palavras foram utilizadas para alcançar o número máximo de pesquisas. Critérios de exclusão foram aplicados para seleção das produções que interessavam a esta pesquisa: pesquisas que se repetiam na coleta com as diferentes palavraschave; estágio supervisionado em outras licenciaturas; estágios realizados em outras graduações/áreas do conhecimento (Enfermagem, Direito, Odontologia, etc.); estágios supervisionados nos cursos de Pedagogia a distância. Os critérios para inclusão e seleção dos trabalhos científicos foram: títulos que mencionam o estágio curricular no curso de Pedagogia; títulos, palavras-chave e resumos que indicassem o estágio em cursos presenciais de Pedagogia; pesquisas sobre o estágio nos cursos de Pedagogia oferecidos em universidades brasileiras; pesquisas concluídas sobre o tema entre os anos de 2000 e 2019.

O levantamento das pesquisas ofereceu algumas limitações: alguns títulos não indicavam a que curso se referiam as pesquisas, necessitando de leitura dos resumos e parte introdutória dos trabalhos; algumas pesquisas não estavam disponíveis no catálogo da Capes e demandaram tempo para serem localizadas nas Bibliotecas Digitais de Teses e Dissertações (BDTD) das universidades, ou não foram encontradas (especialmente aquelas finalizadas nos primeiros anos da década de 2000); alguns títulos não se referiam ao estágio, mas a leitura de partes do trabalho permitiu verificar que se tratava do estágio curricular. Essas limitações evidenciam a necessidade de explicitação do objeto de estudo nos títulos e nas palavra-chave das produções, assim como a explicitação de informações sobre os objetivos, as metodologias, os referenciais teóricos nos resumos, dados que facilitam a localização de pesquisas que serão importantes a outras pesquisas, contribuindo para o avanço do conhecimento científico.

Após a exclusão de pesquisas que não seriam utilizadas neste estudo, seguindo os critérios de inclusão e de exclusão mencionados, foram consideradas pertinentes 68 dissertações e 28 teses, totalizando 96 produções. O Quadro 1 apresenta uma síntese do número de teses e dissertações realizadas em cada região brasileira, distribuídas em 50 Instituições de Ensino Superior (IES). 
A epistemologia de Paulo Freire na formação de pedagogas(os) durante os Estágios Curriculares...

Quadro 1 - Número de teses e dissertações por regiões brasileiras

\begin{tabular}{|c|c|c|l|}
\hline Região & Mestrado & Doutorado & \multicolumn{1}{c|}{ Instituições } \\
\hline Sudeste & 26 & 16 & $\begin{array}{l}\text { UFRRJ - UFJF - UNESP (Araraquara, Rio } \\
\text { Claro, Presidente Prudente, Marília) - UCP- } \\
\text { UNIUBE - ESTÁCIO DE SÁ - UNISANTOS } \\
- \text { UNICAMP - UNICID - UFSCar - PUC-SP } \\
\text { - UEMG - UNISO - USP - UFES - PUC- } \\
\text { Campinas - UFTM - UNIMEP - UFF - UFRJ }\end{array}$ \\
\hline Sul & 19 & 5 & $\begin{array}{l}\text { UFRGS - UNISINOS - UEL - UFSM - FURB } \\
\text { PUCPR - UFPEL - UNIVALI - } \\
\text { UNOCHAPECÓ - UNIJUI - UFSC - PUCRS } \\
\text { - UFPR }\end{array}$ \\
\hline Nordeste & 16 & 6 & $\begin{array}{l}\text { UFPI - UNEB - UFRN - UERN - UECE - } \\
\text { UFCE - UFPE - UFBA }\end{array}$ \\
\hline Centro-oeste & 5 & 1 & UNEMAT - UFMT - UCDB/MS - UFG ${ }^{5}$ \\
\hline Norte & 2 & - & UEPA - UFAM ${ }^{6}$ \\
\hline Total & $\mathbf{6 8}$ & $\mathbf{2 8}$ & \\
\hline
\end{tabular}

Fonte: Elaborado pela autora a partir de dados coletados no Catálogo de Teses e Dissertações da Capes (www.catalogodeteses.capes.gov.br).

De acordo com o Quadro 1, verifica-se que 42 pesquisas sobre os Estágios Curriculares Supervisionados nos cursos de Pedagogia (26 dissertações e 16 teses) foram realizadas na região Sudeste, distribuídas por 23 instituições de Ensino Superior; 24 pesquisas (19 dissertações e cinco teses) foram desenvolvidas na região Sul, em 13 instituições; 22 pesquisas (16 dissertações e seis teses) ocorreram na região Nordeste, em oito instituições; seis pesquisas foram feitas na região Centro-Oeste, em quatro instituições; e duas dissertações foram realizadas em duas instituições da região Norte. Ao todo, 50 programas de Pós-Graduação em Educação, de universidades (públicas e privadas) brasileiras, indicaram inserção no campo de conhecimento do Estágio Supervisionado ao longo do período estudado (2000-2019). A Tabela 1 mostra a distribuição do número de pesquisas produzidas sobre o Estágio Curricular Supervisionado a cada cinco anos.

\footnotetext{
2 UFRRJ - Universidade Federal Rural do Rio de Janeiro; UFJF - Universidade Federal de Juiz de Fora; UNESP Universidade Estadual Paulista "Júlio de Mesquita Filho"; UCP- Universidade Católica de Petrópolis; UNIUBE Universidade de Uberaba; UNISANTOS - Universidade Católica de Santos; UNICAMP - Universidade Estadual de Campinas; UNICID - Universidade Cidade de São Paulo; UFSCar - Universidade Federal de São Carlos; PUC-SP Pontifícia Universidade Católica de São Paulo; UEMG - Universidade do Estado de Minas Gerais; UNISO Universidade de Sorocaba; USP - Universidade de São Paulo; UFES - Universidade Federal do Espírito Santo; PUCCampinas - Pontifícia Universidade Católica de Campinas; UFTM - Universidade Federal do Triângulo Mineiro; UNIMEP - Universidade Metodista de Piracicaba; UFF - Universidade Federal Fluminense; UFRJ - Universidade Federal do Rio de Janeiro.

${ }^{3}$ UFRGS - Universidade Federal do Rio Grande do Sul; UNISINOS - Universidade do Vale do Rio dos Sinos; UEL - Universidade Estadual de Londrina; UFSM - Universidade Federal de Santa Maria; FURB - Universidade Regional de Blumenau; PUCPR - Pontifícia Universidade Católica do Paraná; UFPEL - Universidade Federal de Pelotas; UNIVALI - Universidade do Vale do Itajaí; UNOCHAPECÓ - Universidade Comunitária da Região de Chapecó; UNIJUÍ - Universidade Regional do Noroeste do Estado do Rio Grande do Sul; UFSC - Universidade Federal de Santa Catarina; PUCRS - Pontifícia Universidade Católica do Rio Grande do Sul; UFPR - Universidade Federal do Paraná.

${ }^{4}$ UFPI - Universidade Federal do Piauí; UNEB - Universidade do Estado da Bahia; UFRN - Universidade Federal do Rio Grande do Norte; UERN - Universidade do Estado do Rio Grande do Norte; UECE - Universidade Estadual do Ceará; UFCE - Universidade Federal do Ceará; UFPE - Universidade Federal de Pernambuco; UFBA Universidade Federal da Bahia.

${ }^{5}$ UNEMAT - Universidade do Estado de Mato Grosso; UFMT - Fundação Universidade Federal de Mato Grosso; UCDB/MS - Universidade Católica Dom Bosco/Mato Grosso do Sul; UFG - Universidade Federal de Goiás.

${ }^{6}$ UEPA - Universidade do Estado do Pará; UFAM - Universidade Federal do Amazonas.
}

Práxis Educativa, Ponta Grossa, v. 15, e2017067, p. 1-23, 2020 Disponível em: <https://www.revistas2.uepg.br/index.php/praxiseducativa> 
Tabela 1 - Número de pesquisas realizadas em cada quinquênio do período estudado (2000-2019)

\begin{tabular}{c|c|c|c|c}
\hline Região & $\mathbf{2 0 0 0 - 2 0 0 4}$ & $\mathbf{2 0 0 5 - 2 0 0 9}$ & $\mathbf{2 0 1 0 - 2 0 1 4}$ & $\mathbf{2 0 1 5 - 2 0 1 9}$ \\
\hline Sudeste & 1 & 4 & 17 & 20 \\
\hline Sul & 0 & 4 & 11 & 9 \\
\hline Nordeste & 1 & 2 & 8 & 11 \\
\hline Centro-Oeste & 0 & 1 & 4 & 0 \\
\hline Norte & 0 & 1 & 1 & 0 \\
\hline
\end{tabular}

Fonte: Elaborada pela autora a partir de dados coletados no Catálogo de Teses e Dissertações da Capes (www.catalogodeteses.capes.gov.br).

Os dados informados na Tabela 1 indicam que as produções científicas de Mestrado e Doutorado se intensificaram a partir de 2010 nas regiões Sudeste, Sul e Nordeste. O menor número de produções nas regiões Centro-Oeste e Norte podem ter ocorrido devido ao número reduzido de programas de Pós-Graduação em Educação em relação às demais regiões e não, necessariamente, pela falta de interesse no tema. O número ínfimo de produções científicas entre os anos de 2000 e 2009, em todas as regiões, pode estar relacionado à indisponibilidade dos trabalhos desse período em bibliotecas digitais de teses e dissertações das universidades e na plataforma da Capes. Afinal, na busca realizada para esta pesquisa, no catálogo de teses e dissertações da Capes, 26 produções científicas foram identificadas, mas precisaram ser descartadas, pois não estavam disponíveis on-line.

Das 26 produções (21 dissertações e cinco teses), 10 apresentavam no título a palavra "estágio" relacionada ao curso de Pedagogia, 13 delas apresentavam a palavra "estágio", mas não havia evidências de que tratassem do curso de Pedagogia, e três não indicavam as palavras "estágio" e "Pedagogia" no título. Do total das 26 pesquisas, três eram do ano de 2001, cinco foram publicadas em 2003, cinco constavam no ano de 2004, cinco eram de 2005, quatro constavam no ano de 2006. Além disso, verificou-se que, nos anos de 2009, 2010, 2012 e 2018, uma pesquisa correspondente a cada ano não estava on-line. Nesse caso, podem não ter sido publicadas por decisão de seus autores e de suas autoras.

Em relação ao referencial teórico utilizado nas produções científicas encontradas no catálogo de teses e dissertações da Capes, 28 dissertações e sete teses (35 pesquisas do total de 96) não apresentavam obras de Paulo Freire em suas referências bibliográficas; 63 produções utilizam o referencial teórico desse pensador (43 dissertações e 20 teses). A Tabela 2 indica as obras e os textos citados nas produções.

Tabela 2 - Referências bibliográficas de Paulo Freire nas dissertações e teses (2000-2019)

\begin{tabular}{|c|c|c|c|}
\hline Referências de Paulo Freire & Dissertações & Teses & Total \\
\hline Pedagogia da autonomia & 36 & 14 & 50 \\
\hline Pedagogia do oprimido & 12 & 9 & 21 \\
\hline Extensão ou comunicação & 5 & 4 & 9 \\
\hline Medo e ousadia & 4 & 1 & 5 \\
\hline Política e educação & 3 & 2 & 5 \\
\hline A educação na cidade & 3 & 1 & 4 \\
\hline Professora sim, tia não & 2 & 4 & 6 \\
\hline Pedagogia da indignação & 2 & 1 & 3 \\
\hline Pedagogia da esperança & 2 & 4 & 6 \\
\hline Educação e mudança & 2 & 5 & 7 \\
\hline Educação como prática da liberdade & 2 & 4 & 6 \\
\hline Conscientização: teoria e prática da libertação & 2 & 1 & 3 \\
\hline Ação cultural para a liberdade e outros escritos & 2 & 1 & 3 \\
\hline A escola é & 2 & 1 & 3 \\
\hline Sobre educação: diálogos. Volume 1 & 1 & - & 1 \\
\hline Por uma pedagogia da pergunta & 1 & - & 1 \\
\hline Cartas a Cristina & 1 & 1 & 2 \\
\hline
\end{tabular}

Práxis Educativa, Ponta Grossa, v. 15, e2017067, p. 1-23, 2020 Disponível em: < https://www.revistas2.uepg.br/index.php/praxiseducativa> 
A epistemologia de Paulo Freire na formação de pedagogas(os) durante os Estágios Curriculares...

\begin{tabular}{|c|c|c|c|}
\hline Referências de Paulo Freire & Dissertações & Teses & Total \\
\hline Consciência e história & - & 1 & 1 \\
\hline A importância do ato de ler & - & 1 & 1 \\
\hline $\begin{array}{l}\text { O papel de organismos governamentais na educação básica de } \\
\text { jovens eadultos }\end{array}$ & - & 1 & 1 \\
\hline
\end{tabular}

Fonte: Elaborada pela autora a partir de dados coletados no Catálogo de Teses e Dissertações da Capes (www.catalogodeteses.capes.gov.br).

A Tabela 2 evidencia que a obra mais citada (50 citações) nas pesquisas de Mestrado e Doutorado sobre os Estágios Curriculares Supervisionados nos cursos de Pedagogia, no período de 2000 a 2019, é Pedagogia da autonomia. Ana Maria de Araújo Freire (2006) esclarece, na obra biográfica Paulo Freire: uma história de vida, que o livro foi lançado no dia 10 de abril de 1997; foi, assim, a última obra concluída em vida pelo autor. Nesse livro, Ana Maria de Araújo Freire (Nita) tratou dos saberes necessários à prática pedagógica progressista, aprofundando as qualidades do educador revolucionariamente progressista, esperançoso e defensor de uma prática educativa libertadora. O livro expressa uma densidade de ideias que sintetiza questões fundamentais para a formação dos educadores e das educadoras, com rigor e sem prescrições ou regras, destacando posturas pessoais e epistemológicas abertas à cognoscibilidade.

Nita Freire (2006) destaca a linguagem poética e política, inquietante, problematizadora e amorosa do decidir e do optar pela ação transformadora expressa no livro. Demonstrando autêntica crença nos homens e nas mulheres, e na educação como caminho necessário para a justiça e a paz, nesse livro Freire faz um chamamento aos educadores e às educadoras para se engajarem politicamente na educação libertadora para o ser mais, com ética crítica, competência científica e amorosidade autêntica. Em 2005, Pedagogia da autonomia, de Paulo Freire, contava com 650.000 exemplares vendidos no Brasil (FREIRE, A. M. de A., 2006)

Ao sintetizar sua pedagogia do oprimido na Pedagogia da autonomia, Paulo Freire compartilha com seus leitores e suas leitoras seu profundo compromisso e envolvimento com a formação ética, crítica, política dos educadores e das educadoras e explicita os saberes fundamentais a essa formação e à prática educativo-progressista, como ele mesmo expressa em suas Primeiras Palavras, introduzindo discussões sobre a essência da obra (FREIRE, P., 2014). O livro é, portanto, de grande relevância para leitura de professoras e de professores em formação, porém não pode ser tratado de forma desarticulada da Pedagogia do oprimido (FREIRE, P., 2004), que lança os alicerces epistemológicos para as discussões de obras editadas posteriormente. Entretanto, é preciso esclarecer que a Pedagogia do oprimido também foi revista por Paulo Freire em alguns aspectos na Pedagogia da Esperança: um reencontro com a Pedagogia do oprimido (FREIRE, P., 2003). Por isso, a leitura da produção do autor em processo é de fundamental importância para compreender sua pedagogia progressista e radical.

A Pedagogia do oprimido (FREIRE, P., 2004) aparece como segunda obra mais citada nas teses e nas dissertações (21 produções). Essa obra destacou-se por colocar o autor como referência mundial no campo das Ciências Sociais e da Educação. Iniciada em 1967 no Chile, durante seu exílio provocado pela Ditadura Militar em 1964, a obra foi completada em 1968 e teve sua primeira publicação em inglês em 1970. Nesse livro, Paulo Freire analisa a consciência oprimida e a opressora constituindo-se na realidade objetiva, estudando-as em sua dialeticidade e colocando a questão da superação da contradição entre elas, da qual resulta o homem novo e a mulher nova, libertando-se. Depois, realiza críticas aos fundamentos de uma educação bancária da educação, dedicada ao depósito de falsos saberes, e descreve a educação como prática da liberdade, instaurada como situação gnosiológica em que educador-educando e educando-educador se fazem sujeitos em diálogo, mediatizados pelo objeto cognoscível. Na terceira parte do livro, Freire trata da dialogicidade da educação, que parte da busca do conteúdo programático da educação, que não

Práxis Educativa, Ponta Grossa, v. 15, e2017067, p. 1-23, 2020 Disponível em: <https://www.revistas2.uepg.br/index.php/praxiseducativa> 
pode ser tratado apenas pelo lado do educador ou educadora, pois implica no conhecimento do pensar do povo. Finalmente, na quarta parte do livro, o autor analisa as teorias da ação que nasceu das matrizes dialógica e antidialógica (FREIRE, A. M. de A., 2006).

Das 96 pesquisas, 31 dissertações e 13 teses utilizaram uma ou duas obras de Paulo Freire como parte de seu referencial teórico; 11 dissertações e oito teses utilizaram três ou mais obras de Freire. Desperta especial atenção uma dissertação que adota Paulo Freire como referencial fundamental para a pesquisa, indicando o estudo de 10 obras do autor e seu nome no título e nas palavras-chave: Estágio Curricular Supervisionado no curso de Pedagogia: diálogo entre universidade e escola à luz de Paulo Freire, de Ana Maria do Nascimento, dissertação concluída em 2014 na Universidade Estadual do Ceará e orientada pela professora Maria Socorro Lucena Lima. Destaca-se, também, uma tese que utiliza 11 referências de Paulo Freire, mas não indica o autor no título ou palavraschave. Portanto, ele não aparece como referência que orienta a pesquisa, mas tem presença relevante entre as teorias estudadas. Trata-se da tese O Estágio Curricular Supervisionado em espaços não escolares no Curso de Pedagogia da Universidade do Estado da Babia (UNEB): as contribuições do percurso formativo (2017), de Ana Lúcia Pereira, orientada pela professora Marina Graziela Feldmann.

A Tabela 2 evidencia, portanto, que Paulo Freire é referenciado na maioria das pesquisas coletadas e a significativa presença da Pedagogia da autonomia nas dissertações e nas teses encontrase na relação que a obra apresenta com o campo de conhecimento do Estágio Curricular Supervisionado e da formação dos professores, expressa na ênfase dos temas escolhidos. Os objetos de estudo das pesquisas de Mestrado e Doutorado, que apresentam referenciais de Paulo Freire, estão relacionados a problemáticas que envolvem:

- experiências formativas no estágio curricular e no PIBID;

- contribuições do estágio para a construção da identidade docente;

- contribuições do estágio para a relação teoria-prática;

- contribuições do estágio para a formação reflexiva de professores;

- sentidos atribuídos à docência durante os estágios;

- concepção de estágio na proposta dos cursos de Pedagogia;

- concepção de estágio por parte das pessoas envolvidas com ele;

- compromisso da escola com a formação de professores durante os estágios;

- relação do estágio e a fase inicial da docência;

- a prática pedagógica desenvolvida durante os estágios;

- a dimensão ética e estética da Educação no espaço escolar durante os estágios;

- relações entre estudantes estagiários e outros profissionais envolvidos na atividade de estágio (professoras da escola, docentes da universidade, estudantes da escola);

- o diálogo entre universidade e escola a partir do estágio;

- compreensão do estágio a partir de determinadas teorias;

- análise da própria experiência como orientador/a dos estágios na universidade;

- professoras das escolas como formadoras dos estudantes estagiários;

- contribuições do estágio para a constituição de saberes docentes;

- constituição dos estudantes como sujeitos de conhecimento durante os estágios;

- o estágio como espaço de aprendizagens profissionais;

- o estágio em espaços não escolares;

- a relação entre atividades de extensão e o estágio.

Observa-se que variados temas estão envolvidos nos estudos sobre o estágio e são abordados a partir de contribuições de Paulo Freire. Contudo, somente um deles optou por Paulo 
A epistemologia de Paulo Freire na formação de pedagogas(os) durante os Estágios Curriculares...

Freire como base teórica. Assim como a pesquisa de Nascimento (2014), esta pesquisa também é orientada pela epistemologia de Paulo Freire, cujas construções conceituais fundadoras de uma pedagogia problematizadora e libertadora são identificadas por meio dos procedimentos da pesquisa bibliográfica.

\section{Os caminhos da pesquisa}

A origem desta pesquisa está situada no contexto de trabalho que realizo como orientadora dos Estágios Curriculares Supervisionados em Docência nos anos iniciais do Ensino Fundamental no curso de Pedagogia. Os estágios, cuja carga horária de 102 horas ocorre nos $3^{\text {os }}$ e $4^{\text {os }}$ anos do curso, mostravam-se como uma experiência "impactante" para as(os) estagiárias(os), como revelam os Trabalhos de Conclusão de Curso (TCC) que orientei nos anos de 2016 (SILVA, 2016; DAMBROSKI, 2016) e, posteriormente, reafirmados nos registros das(os) estudantes nos anos subsequentes. Apesar de iniciarem o contato com as escolas em outras disciplinas, antes de iniciarem os estágios, foi durante os últimos anos do curso que as(os) alunas e alunos têm a oportunidade de atuarem como professoras e professores, realizando 51 horas de atividades no campo - Escolas Municipais de Ensino Fundamental: 31 horas de observação e 20 horas de regência de classe.

Os momentos de planejamento e regência de aulas constituem grandes desafios e geram muita ansiedade nas(os) futuras(os) professoras(es) em formação, pois oferecem a oportunidade de viverem o processo de ensinar e aprender a ensinar melhor nas relações com as crianças, conhecendo as peculiaridades de cada uma e da turma na qual se inserem, o contexto da escola, sua organização e seu funcionamento. Além disso, após a aproximação com a professora e a turma de crianças, participar das ações educativas e buscar compreender o processo pedagógico desenvolvido com elas, durante as 31 horas de observação, assumem a tarefa complexa de planejar os conteúdos. Planejar os conteúdos não significa meramente criar uma sequência de atividades consideradas "interessantes". Planejar é uma práxis exigente, que demanda reflexão e posicionamento político sobre o que significa ser professor(a), sobre como são vistos(as) os(as) alunos(as), sobre a visão que se tem dos conteúdos e de suas relações com a realidade, sobre o que se pensa no momento de selecionar os recursos e os procedimentos para o trabalho com os conteúdos, o uso do tempo e dos espaços, entre outros aspectos (FREIRE, P., 2008).

Ao receber a primeira versão dos planejamentos e analisá-los, a fim de conhecer como as(os) alunas(os) pensavam a prática pedagógica, para que pudesse orientar detalhadamente cada etapa da aula com cada aluna(o) para as regências de aulas (cinco planejamentos referentes a cada estudante), verifiquei que alguns problemas eram recorrentes. As práticas expressavam a imitação de modelos, a instrumentalização técnica sem reflexão, a falta de relação entre teoria e prática (PIMENTA; LIMA, 2011), o que alertava para a necessidade do desenvolvimento de um olhar multidimensional, problematizador e crítico à tarefa de planejar, considerando sua complexidade. Alertava também para a ingenuidade de concebermos os estágios como espaço privilegiado de articulação dos conhecimentos tratados durante todo o curso, atribuindo-lhe a responsabilidade da preparação para a docência, sem apreender suas limitações, que refletem limitações do próprio curso. Afinal, como afirma Aroeira (2014):

Refletir sobre a formação docente implica conceber a perspectiva de coformação e assumir que o estágio não é responsável por promover a práxis de um curso de formação de professores, mas, quando este considera práticas de partilha com a escola, aspectos de colaboração e reflexividade, assim como de pesquisa e de interdisciplinaridade, pode cumprir de modo institucional, numa perspectiva emancipatória, a função de colaborar num processo formativo a favor da unidade teoria e prática. (AROEIRA, 2014, p. 145146).

Práxis Educativa, Ponta Grossa, v. 15, e2017067, p. 1-23, 2020

Disponível em: < https://www.revistas2.uepg.br/index.php/praxiseducativa> 
Em uma perspectiva dialética, reconhecer que os Estágios Curriculares Supervisionados apresentam limitações significa compreender que ele carrega possibilidades, situações que se traduzem em desafios para as orientadoras e os orientadores de estágio e também para as demais áreas do conhecimento. Nesse sentido, não é possível desconsiderar a necessidade de repensar o lugar da prática no currículo do curso, a carga horária destinada a ela, as relações estabelecidas entre universidades, sistemas de ensino e equipes escolares, as diferentes concepções assumidas sobre os processos educativos e a formação de professores(as). No entanto, dentro das possibilidades, os Estágios Curriculares Supervisionados podem criar oportunidades para que as(os) estagiárias(os) se experimentem como educadoras(es) mediante uma perspectiva crítica, dialógica, problematizadora e curiosa de atuar pedagogicamente e relacionar-se com as crianças, assumindo o compromisso com a própria formação voltada ao desvelamento da realidade e à diminuição das desigualdades sociais.

Diante desse cenário, o problema colocado para a pesquisa foi a definição de caminhos epistemológicos para a orientação e o acompanhamento dos estágios, em uma perspectiva progressista que não dicotomizasse a formação científica da aprendizagem que se dá pelo corpo consciente; que não provocasse a ruptura entre competência técnica e o compromisso político e ético, apostando nas relações dialógicas. Esse caminho foi encontrado na Pedagogia do oprimido de Paulo Freire, considerando que ele desenvolveu um pensamento educacional comprometido com a vida, com a existência humana (FIORI, 2004), que se tornou um grande projeto coletivo, repensado, recriado e reconstruído por inúmeros(as) educadores(as) em todas as partes do mundo, nas escolas, nas universidades, nos movimentos sociais e nas organizações comunitárias (ANDREOLA, 2001). A atualidade da educação emancipadora e humanista de Paulo Freire é afirmada pela realidade social e cultural que o alimentou e que ainda continua viva, em tempos de brutal desumanização das camadas populares, nos quais assistimos a diferentes formas de exclusão e de opressão que se alastram mediante a globalização e o neoconservadorismo, contexto que demanda entendimento da dramaticidade que o envolve (ARROYO, 2001).

No intuito de planejar caminhos para uma formação ética, crítica, problematizadora, humana, rigorosa cientificamente e comprometida com as crianças que frequentam as escolas públicas, durante os Estágios Curriculares Supervisionados do curso de Pedagogia, foram delineados os seguintes objetivos para esta pesquisa:

a) Investigar, nas construções teóricas e nas ações dialógicas do "método de alfabetização" de Paulo Freire, contribuições para a organização didática dos Estágios Curriculares Supervisionados no curso de Pedagogia.

b) Sistematizar orientações teóricas e práticas para os Estágios Curriculares Supervisionados, em uma perspectiva problematizadora e crítica, a partir da práxis freiriana.

A pesquisa é de abordagem qualitativa, pois, conforme Triviños (1987), realiza estudos sobre um fenômeno social, privilegiando a prática e o propósito transformador do conhecimento que emerge da realidade, a qual se busca desvendar em seus aspectos essenciais e acidentais. A pesquisa qualitativa é caracterizada por sua natureza desreificadora dos fenômenos, do conhecimento e do ser humano e rejeita a neutralidade do saber científico. Além disso, configurase como pesquisa que tem a realidade concreta como fonte de dados, considerando a visão ampla e complexa sobre ele; é descritiva e tende a uma análise indutiva dos dados coletados; preocupa-se com os significados identificados no processo e não apenas com os resultados e o produto da investigação; não segue uma sequência tão rígida de etapas de seu desenvolvimento; as informações recolhidas e interpretadas podem exigir novas buscas de dados (TRIVIÑOS, 1987; BOGDAN; BIKLEN, 1994). 
A epistemologia de Paulo Freire na formação de pedagogas(os) durante os Estágios Curriculares...

Bogdan e Biklen (1994) explicam que, em uma investigação de abordagem qualitativa, se parte da ideia de que nada é trivial e tudo tem potencial como pista para uma compreensão mais esclarecedora do objeto de estudo. E, por constituir-se como atividade humana e social, a pesquisa carrega valores, preferências, interesses e princípios que orientam o(a) pesquisador(a), assim como é influenciada por elementos condicionantes de um determinado tempo e de um contexto específico. Segundo Lüdke e André (1986):

\begin{abstract}
Assim, a sua visão do mundo, os pontos de partida, os fundamentos para a compreensão e explicação desse mundo irão influenciar a maneira como ele propõe suas pesquisas ou, em outras palavras, os pressupostos que orientam seu pensamento vão também nortear sua abordagem de pesquisa. (LÜDKE; ANDRÉ, 1986, p. 3).
\end{abstract}

Dentro dessa abordagem de pesquisa, a opção foi feita pela pesquisa bibliográfica, que é realizada a partir do registro disponível sobre pesquisas anteriores ou documentos impressos, como livros, artigos, teses, etc., cujos textos constituem fontes dos temas a serem pesquisados. "O pesquisador trabalha a partir das contribuições dos autores dos estudos analíticos constantes nos textos." (SEVERINO, 2007, p. 122).

A pesquisa bibliográfica é construída por meio de um conjunto ordenado de procedimentos, visando a busca de soluções, considerando o objeto de estudo e os objetivos propostos (LIMA; MIOTO, 2007) De acordo com Marconi e Lakatos (2003), esse tipo de pesquisa compreende oito fases: a escolha do tema e sua delimitação, evitando assuntos que foram estudados recentemente; a elaboração do plano de trabalho; identificação do assunto pertinente ao tema estudado; localização das referências bibliográficas; compilação sistemática do material; fichamento para ordenação dos assuntos; análise e interpretação para apreciação do sentido e do valor do conteúdo, decompondo e classificando seus elementos essenciais; e, por fim, redação.

Os procedimentos metodológicos usados na pesquisa bibliográfica obedecem a uma sequência que compreende quatro fases que compõem um processo contínuo, na qual cada etapa pressupõe aquela que a precede e se completa na seguinte (SALVADOR, 1986): formulação do problema e elaboração de um plano para busca de respostas às questões formuladas; levantamento bibliográfico e das informações contidas na bibliografia; análise crítica da documentação; síntese integradora, como resultado da análise e reflexão sobre o material.

As leituras sucessivas do material demandam técnicas para a obtenção de informações em cada momento da pesquisa: leitura para seleção dos materiais que apresentam informações sobre o tema; leitura exploratória para verificar informações relevantes, seguindo os objetivos; leitura seletiva das informações pertinentes; leitura crítica para ordenar e sumarizar as informações selecionadas; leitura interpretativa para estabelecer relações entre os conceitos encontrados nas obras e o problema delimitado (SALVADOR, 1986). A rigorosidade na execução de cada leitura garante a consistência na análise do material, o que proporciona um vasto e rico campo de possibilidades de novos temas ainda não explorados.

A epistemologia de Paulo Freire, escolhida como fundamento para esta pesquisa e para as práticas educativas relacionadas ao Estágio Curricular Supervisionado, durante a formação inicial no curso de Pedagogia, configura-se como uma teoria dual que implica estar no mundo, com o mundo e com os outros, um mundo que é histórico, cultural, no qual existimos e não apenas vivemos, pelo qual somos condicionados(as) mas não determinados(as). As bases dessa epistemologia são constituídas por pares dialéticos que expressam uma atitude relacional, fundante em sua pedagogia, por meio de aproximações, de articulações, de unidade, como subjetividadeobjetividade, sujeito-objeto, dimensão individual-social, teoria-prática, ensinar-aprender, textocontexto, educador-educando. As relações estabelecidas nessas bases são dinâmicas e buscam a 
totalização, afastando-se da fragmentação, como compreensão de diferentes que se constituem e constituem significados e explicações sócio-político-filosóficas (SANTIAGO, 2004).

Como produção de conhecimento que se dá de forma intersubjetiva, dialética e dialogicamente aberta ao dinamismo da vida, à diferença e ao inédito viável, inspira inovações na visão política e ética dos problemas que desafiam o mundo atual. Paulo Freire recoloca a relação dialética e diálogo oferecendo novos fundamentos que superam a clássica tríade dialética da modernidade ocidental, expressa nos termos hegelianos afirmação - negação - negação da afirmação, pois parte da realidade concreta dos seres humanos desumanizados, problematizando o mundo por meio do diálogo crítico e transformador das culturas (ZITKOSKI, 2008).

Na dialética-dialógica de Paulo Freire, uma posição não se sobrepõe à outra, pois o diálogo autêntico nutre-se pela abertura aos outros, podendo anunciar a revelação do novo na história, que não está predeterminado ou domesticado pelo momento histórico anterior. O futuro é construído pela inserção das pessoas no mundo e a história é constituída de contradições, tensões, conflitos que impulsionam os seres humanos para novos sentidos da vida. Pelo exercício do diálogo, as diferentes posições têm condições iguais de serem ouvidas, debatidas e avaliadas, pois funda-se na busca da libertação de todos(as) e não no controle dela em uma perspectiva histórica determinista (ZITKOSKI, 2008).

Dessa forma, entendemos que Freire buscou elaborar novas bases filosóficas (antropológica, epistemológica, política e eticamente), que nos oportunizam discutir alternativas para a sociedade e a existência humana na contemporaneidade - capaz de garantir um sentido libertador, humanista, radicalmente democrático e solidário na organização, produção e recriação da vida em sociedade. (ZITKOSKI, 2008, p. 129).

Estar em diálogo para Paulo Freire significa, portanto, estar com o mundo e com os outros, refletindo, avaliando, programando, investigando e transformando especificidades dos seres humanos no mundo e com o mundo. Nesse sentido, a educação é pensada por Freire a partir da existência humana e, portanto, é incompatível com uma pedagogia como prática de dominação, pois o diálogo é definido pela palavra encarnada pela ação e pela reflexão (BRAGA; GABASSA; MELLO, 2010).

Considerando que os pares dialéticos fundantes da epistemologia de Paulo Freire estruturam-se em uma rede de relações, um entre eles terá destaque neste texto e não poderá ser compreendido fora dessa rede - educação problematizadora-educação bancária. Esse par dialético ganha sentido na medida em que exprime a presença dos demais (subjetividade-objetividade, humanização-desumanização, libertação-dominação, transformação-adaptação, oprimidoopressor, seres condicionados-seres determinados, sectarização-radicalização, denúncia-anúncio, síntese cultural-invasão cultural, leitura de mundo e leitura da palavra, docência e discência, e outros) (PAULA, 2011).

Os procedimentos referentes à pesquisa bibliográfica permitiram a identificação, localização e codificação das concepções em pares dialéticos, bem como a construção da rede de relações entre eles por meio do processo de sucessivas leituras (SALVADOR, 1986). Tal processo requer muita atenção e rigorosidade considerando que o autor retoma continuamente as categorias teóricas já citadas ao introduzir uma nova categoria. 
A epistemologia de Paulo Freire na formação de pedagogas(os) durante os Estágios Curriculares...

\section{Resultados da pesquisa e suas contribuições para os estágios: a pedagogia problematizadora e libertadora de Paulo Freire}

A melhoria da qualidade do ensino e das aprendizagens dos alunos e alunas nas escolas de Educação Básica demanda formação inicial e contínua dos educadores e das educadoras, mas ela não é o único fator responsável por essa melhoria. A valorização dos profissionais do magistério, as boas condições de trabalho, a garantia de salários dignos, a destinação de recursos para manutenção das escolas, o estreitamento de relações entre universidades e sistemas de ensino são condições igualmente importantes para a qualidade dos processos educativos. As políticas de formação não podem se dissociar das políticas de valorização dos profissionais da Educação Básica, de carreira e de salários (OLIVEIRA; LEIRO, 2017; JACOMINI; PENNA, 2016), fazendo recair sobre os professores a exclusiva responsabilidade pelos baixos resultados das avaliações, ignorando a produção científica nacional e desprezando e negando a necessidade de uma sólida formação teórica, em favor de uma orientação técnico-instrumental (ANPED, 2019), como pode-se constatar nas Diretrizes Curriculares Nacionais para a Formação Inicial de Professores para a Educação Básica (BRASIL, 2019).

Como apontam os temas trabalhados nas teses e nas dissertações estudadas, o estágio curricular nos cursos de Pedagogia representa um rico espaço de construção das identidades e dos saberes docentes, propicia a indissociabilidade entre teoria e prática e a reflexão sobre as práticas pedagógicas e sua relação com o ato de planejar, provoca a constituição de sentidos em relação à profissão e possibilita a definição de escolhas sobre ser ou não ser professor ou professora, pela oportunidade de mover-se dentro dos contextos escolares, com alunos e equipes profissionais. Fazse, também, um espaço especialmente importante para verificar como as políticas para a educação e formação de professores(as) impactam na organização e no funcionamento dos sistemas de ensino, nas concepções que educadoras e educadores têm sobre educação e nas práticas pedagógicas. Dessa forma, todo o curso é colocado em questionamento no momento que os e as estudantes iniciam os estágios curriculares, considerando que os conhecimentos provenientes das diferentes áreas são chamados para responder às situações-problema configuradas nas relações humanas mediadas pelos processos de ensinar e de aprender.

Apesar da importância enfatizada sobre o estágio pelas produções científicas, tenho constatado, a partir de trabalhos em que pude articular a experiência dos estágios curriculares a pesquisas do Programa Institucional de Bolsas de Iniciação Científica (PIBIC) e projetos junto às escolas, que as aprendizagens efetivadas por meio deles são potencializadas quando relacionadas à pesquisa e à extensão na universidade, atividades que colaboram para o amadurecimento e a segurança nas ações de planejar e de ensinar. Isolado da relação ensino-pesquisa-extensão, limitado a um trabalho disciplinar dentro do curso de Pedagogia, distante das discussões que permeiam todo o curso, os estágios curriculares ficam enfraquecidos e não alcançam as preocupações de todos e todas que participam da formação das futuras professoras e dos futuros professores.

Buscando investir em uma formação crítica, humanista, ética e rigorosamente científica durante os estágios curriculares no curso de Pedagogia, tenho agregado ações de extensão, pesquisa e atualização didática (programa destinado a egressos do curso), fundamentadas na epistemologia de Paulo Freire. Essas ações, quando articuladas, evidenciam melhor desempenho nas atividades acadêmico-científicas e nas atividades docentes por parte dos(as) estudantes e, consequentemente, uma relação concreta entre teoria e prática sob a perspectiva progressista de Paulo Freire.

O compromisso político com a emancipação das pessoas e grupos oprimidos, que denuncia processos de desumanização, exclusão e discriminação na sociedade, representa a força motora de seus trabalhos pedagógicos e suas produções científicas, plenos de sensibilidade amorosa e

Práxis Educativa, Ponta Grossa, v. 15, e2017067, p. 1-23, 2020

Disponível em: <https://www.revistas2.uepg.br/index.php/praxiseducativa> 
esperançosa, que anuncia caminhos humanizadores e críticos de superação das relações desiguais por meio dos processos educativos (ARROYO, 2001) Portanto, cabe perguntar:

[...] a pedagogia freireana tem atualidade? Sim, porque estamos em tempos de brutal desumanização dos setores populares, pois com um mínimo de sensibilidade podemos ter essa dolorosa constatação que a desumanização a cada dia é mais cruel, que a opressão e exclusão se alastram em tempos de globalização. (ARROYO, 2001, p. 166).

Desde o início de suas atividades educativas, a formação de professores e de professoras sempre foi um tema que permeou as preocupações de Paulo Freire, sendo amplamente discutida por ele. "A sua construção sobre esse tema derivou-se, ao mesmo tempo, de inspirações de sua prática, de diálogos que manteve com educadores em redor do mundo e de suas convicções sobre a relevância da formação no ato de educar." (SAUL; SAUL, 2016, p. 24) Em suas primeiras obras, Paulo Freire já sistematizava suas concepções sobre o saber e o fazer docentes, dando ênfase aos fundamentos políticos, filosóficos e antropológicos de sua proposta para a compreensão da prática docente. Ao longo de sua produção, nas décadas de 1980 e 1990, aprofundou temas específicos sobre o processo ensino-aprendizagem e à formação de professores, principalmente nas obras Medo e ousadia: o cotidiano do professor (publicada em 1987), A educação na cidade (publicada em 1991), Professora sim, tia não: cartas a quem ousa ensinar (publicada em 1993), Política e educação (publicado em 1993) e Pedagogia da autonomia: saberes necessários à prática docente (publicado em 1996) (SAUL; SAUL, 2016).

O estudo sistemático das obras de Paulo Freire, apoiado nos procedimentos da pesquisa bibliográfica (LIMA; MIOTO, 2007; SALVADOR, 1986), permitiu identificar construções conceituais da pedagogia problematizadora como contribuições para a organização didática dos estágios, por meio de orientações teóricas e práticas. Essas orientações mostraram-se necessárias pela observação de que as estagiárias e estagiários apresentavam a tendência de reproduzirem modelos de práticas (PIMENTA; LIMA, 2011) que encontravam nas salas de aulas e que as(os) acompanharam em suas trajetórias escolares, característicos da educação bancária, criticada por Paulo Freire. Para provocar a reflexão sobre esses modelos, instigando a ruptura em relação a eles na atividade de planejar e nas atividades de docência, por meio de estudos, questionamentos e proposições, desenvolvi um conjunto de orientações que colaboravam para a construção dessas atividades e serviam como critérios de avaliação durante o acompanhamento dos estágios. Essas orientações foram organizadas a partir das construções teóricas de Paulo Freire sobre pesquisa, curiosidade epistemológica, dialogicidade, solidariedade, criticidade, leitura de mundo e leitura da palavra, humildade, ética e estética e compromisso político, importantes para a definição da educação problematizadora. Para compreender melhor essas construções conceituais, é preciso enxergá-las nas relações que estabelecem com as concepções de ser humano, mundo e educação.

Como seres inacabados, inconclusos, conscientes desse inacabamento e, portanto, seres históricos, que se fazem e refazem ao moverem os processos históricos, como sujeitos, grupos e classes, somos seres capazes de sentir, refletir, analisar, decidir e agir; enfim, seres éticos. Por sermos capazes de decidir e agir, assumimos opções a partir de nossa inserção no mundo, com o mundo e com os outros, que são tomadas a favor de algo e de alguém e, por isso, contra algo e contra alguém. Nesse sentido, somos seres políticos, condicionados, porém não determinados e, consequentemente, responsáveis em relação às ideias e às práticas que defendemos e que assumimos. Somos seres que amam e se indignam, sonham e constroem caminhos para concretização desses sonhos, movidos(as) pela crença de um novo amanhã, pela esperança e luta na transformação do hoje aterrorizante em um futuro menos feio, menos desigual, menos injusto (FREIRE, P., 2014).

Sob essa perspectiva, como seres inconclusos, inacabados, criamos formas de aprender e de ensinar, de conhecer e de produzir conhecimentos, de buscar soluções para os problemas que 
A epistemologia de Paulo Freire na formação de pedagogas(os) durante os Estágios Curriculares...

se apresentam nas relações que estabelecemos com os outros, em uma determinada realidade objetiva. Por tudo isso, os processos educativos, fruto de nossa ação consciente no mundo, não são neutros e podem contribuir para a formação de pessoas dóceis, conformadas e manipuláveis, ou para a constituição de pessoas questionadoras, inquietas, solidárias, comprometidas com a equidade de oportunidades e de direitos. A primeira forma de educar, chamada por Paulo Freire (2004) de "bancária", parte de uma concepção e uma prática imobilista, que enfatiza a permanência da História, a percepção fatalista das condições objetivas humanas, a negação dos seres humanos como sujeitos capazes de inteligir e criar, e provoca a imersão das pessoas na realidade como objetos, alienados de suas decisões e proibidos de ser, que apenas memorizam e reproduzem informações traduzidas como verdades incontestáveis.

A segunda forma de educar, chamada por Paulo Freire (2004) de problematizadora, parte do caráter histórico e da historicidade dos seres humanos, do desvelamento da realidade, da busca das razões de ser dessa realidade e das condições desiguais e desumanas impostas a alguns em detrimento dos privilégios vividos por outros. É uma educação instigadora da curiosidade, da criticidade, da pergunta, comprometida com as relações igualitárias, respeitosas, tolerantes, dialógicas e, portanto, transformadoras da realidade opressora. Ao analisar as construções teóricas que embasam a educação problematizadora, faço uma discussão sobre sua importância para a organização didática dos estágios e para as orientações oferecidas.

a) Curiosidade epistemológica, criticidade e pesquisa: o educador bancário inibe a curiosidade dos educandos, impondo o silêncio, negando a pergunta, tolhendo a liberdade de conhecer, dificultando o exercício da tensão entre liberdade-autoridade. Nesse sentido, ao domesticarem a curiosidade, educadoras e educadores não aprendem nem ensinam, não questionam e nem se questionam; promovem o adestramento e a submissão; deixam de aproximar-se metodicamente do objeto para desvelá-lo criticamente junto aos(às) educandos(as), burocratizando suas mentes (FREIRE, P., 2003, 2004, 2014; FREIRE; SHOR, 2003). Constantemente, as estagiárias e os estagiários não se perguntavam sobre o que, por que, como, a favor de quê e de quem, contra o que e contra quem planejavam. Selecionavam atividades encontradas na internet sem perguntar-se e refletir sobre elas e o que as crianças aprendiam com elas. Não realizavam pesquisas sobre os conteúdos para aprofundar conhecimentos sobre eles e não tratavam esses conteúdos em todas as suas dimensões (particular, social, histórica). Sempre partiam do conceito para o concreto, supondo que as crianças compreenderiam essa relação direta. Não previam perguntas, apenas tarefas, manifestando a concepção de criança como executora de atividades, memorizadora e reprodutora de informações. Essa atitude provocava diversos problemas com as crianças durante as docências (dispersões, desinteresse, vontade de ausentar-se da sala, conflitos), considerando que as crianças sabem muitas coisas e têm o que dizer sobre os assuntos tratados. Por meio de questionamentos feitos às estagiárias e aos estagiários, para que pensassem as contradições de suas opções e de orientações fundamentadas, compreenderam a importância da pesquisa, da interdisciplinaridade e do tratamento crítico dos conteúdos, do processo de perguntar, conhecer, atuar, mais perguntar, re-conhecer (FREIRE, P., 2014). Instigar as crianças a expressarem conhecimentos e perguntas sobre o conteúdo fez com que as e os estudantes descobrissem o que não sabem e a exercer a humildade de responder: "Vou pesquisar isso que você pergunta e depois trago a resposta!". Descobriram que ensinar e aprender são processos que convocam a imaginação, a intuição, as emoções, a capacidade de conjecturar, de comparar na busca da razão de ser do objeto estudado por todos(as).

b) Dialogicidade, solidariedade, leitura de mundo e leitura da palavra: O diálogo significa autêntico exercício da palavra para pronúncia de mundo, como reflexão e ação, a fim de 
buscar sua transformação. Por isso, ele é direito de todos(as) e a imposição da palavra de uns a outros, silenciando-os, representa um ato violento, que expressa desamor e profunda descrença na capacidade das pessoas de pensar, de falar e de agir. O diálogo proposto por Paulo Freire demanda fé nas pessoas, confiança entre aqueles e aquelas que dele participam pelo testemunho da coerência (correspondência entre o que se diz e o que se faz) e humildade para saber mais com os outros. Portanto, a autossuficiência é incompatível com o diálogo, assim como a falta de esperança, pois esta instaura uma eterna busca, que não se faz no isolamento, mas em solidariedade. A esperança, a fé nas pessoas, o amor a elas e ao mundo, a humildade, a solidariedade são condições para que uma situação gnosiológica ocorra (FREIRE, P., 2004, 2005, 2014). Nesse sentido, as diferenças enriquecem o diálogo pois permitem o conhecimento de um objeto em suas contradições, de forma mais ampla, pelas diferentes contribuições. Por meio do diálogo, as educadoras e os educadores conhecem melhor o que já conheciam e descobrem a leitura de mundo que os(as) educandos(as) trazem para o contexto escolar. Dessa forma, podem caminhar para uma leitura crítica de mundo, discutindo a razão de ser do objeto que conhecem. As estagiárias e os estagiários estavam acostumadas(os) a organizar jogos e procedimentos lúdicos de ensino a partir da competitividade e da formação de grupos por sexo (meninos e meninas). Não analisavam criticamente algumas proposições que continham mensagens preconceituosas, retiradas da internet; não davam oportunidade para que as crianças manifestassem suas ideias e impressões sobre os conteúdos; não controlavam os momentos de fala e escuta nas discussões sobre os conteúdos, estimulando os tímidos à participação e os falantes à escuta atenta e respeitosa do outro. A partir das orientações individuais e coletivas com a professora de estágio, na universidade e nas escolas, compreenderam a necessidade de planejar atividades e organizar a turma para realizá-las tendo em vista a solidariedade, o respeito na exposição de opiniões e ideias, a paciência para ouvir e compreender o ponto de vista dos outros, a importância de aprender em comunhão. Aprenderam que valorizar a participação igualitária de todas as crianças no diálogo possibilitava a elevação da autoestima daquelas que se sentiam menos capazes, por terem determinadas dificuldades, na medida em que seus conhecimentos eram exaltados e contribuíam para ampliar o conhecimento das outras. Ao sentirem-se valorizadas em seus conhecimentos, essas crianças passavam a mostrar mais interesse pelos conteúdos e dispunham-se a ajudar os(as) colegas, compartilhando o que sabiam.

c) Ética, estética e compromisso político: Ao tratar de uma prática educativa progressista, Paulo Freire (2014) enfatiza que decência e boniteza são quefazeres inseparáveis e caminham sempre juntos, pois como seres histórico-sociais nos tornamos capazes de comparar, valorar, intervir, escolher, decidir, romper e, portanto, somos seres éticos. " $\mathrm{E}$ por isso que transformar a experiência educativa em puro treinamento técnico é amesquinhar o que há de fundamentalmente humano no exercício educativo: o seu caráter formador" (FREIRE, P., 2014, p. 34). Se há respeito à natureza do ser humano, o ensino dos conteúdos não pode ocorrer desvinculado da formação moral dos educandos e das educandas. A educação progressista deve ocupar-se da relação entre os aspectos técnico e político, assim como precisa preocupar-se com a pesquisa para a relação entre os conhecimentos populares e o conhecimento científico (FREIRE, P., 2003). Na pedagogia de Paulo Freire, a educação é um processo gnosiológico, estético, ético e político, mas a ética nem sempre é tratada nos cursos de formação de professores. Durante as orientações dos estágios curriculares, sempre insisto na necessidade de relacionar essas quatro dimensões da educação, buscando um tratamento crítico dos conteúdos, que supere a ingenuidade de muitas concepções que aprendemos na trajetória escolar. Refiro-me, por exemplo, à abordagem equivocada de episódios históricos, como chamar de "descobrimento" o que houve em 1500 quando os europeus chegaram às terras brasileiras.

Práxis Educativa, Ponta Grossa, v. 15, e2017067, p. 1-23, 2020

Disponível em: <https://www.revistas2.uepg.br/index.php/praxiseducativa> 
A epistemologia de Paulo Freire na formação de pedagogas(os) durante os Estágios Curriculares...

Como analisa Paulo Freire (2000), o que houve, na verdade, foi conquista, a invasão de um mundo novo de forma predatória dos colonizadores, que impôs seu mandonismo, seu poder avassalador sobre as terras e as gentes, buscando destruir as identidades culturais dos nacionais. Os povos que já habitavam o território brasileiro foram considerados como inferiores, e o corpo e a alma da América foram mutilados, gerando mazelas que carregamos ainda hoje (FREIRE, P., 2000.) Entretanto, Paulo Freire (2000) explica que recusar uma visão "amaciada" da invasão, não significa deixar-se possuir pelo ódio aos europeus. É postura de quem não se acomoda diante da malvadeza das formas de colonialismo, invasão e espoliação, de quem recusa encontrar positividades em um processo por natureza perverso. É postura ética e política, que precisa ser discutida com as futuras professoras e os futuros professores nos cursos de formação para que possam ser desenvolvidas junto às crianças da Educação Básica. Postura que nos impede de mentir. Por isso, os cursos de formação de professores(as) nos colocam a importante exigência de tratar a relação entre conceito e concreto de forma desveladora, curiosa, crítica, pela reflexão constante sobre o que significa ensinar, o que ensinar, como ensinar, como vejo a quem ensino. As crianças cobram essas exigências da prática docente, e isso é explicitamente indicado durante os estágios. Certa vez, descuidando-se da linguagem machista utilizada para discutir um conteúdo de Geografia sobre a diferença entre ambientes naturais e ambientes modificados, uma estagiária explicava que esses últimos ambientes eram produzidos pelo "homem" e foi rapidamente interrompida por uma aluna de segundo ano que disse: "Mas as mulheres também constroem coisas!". Essa situação denuncia que a linguagem que usamos é utilizada para comunicar formas de pensar e expressa uma cultura que pode estar impregnada por sentidos machistas ou racistas, por exemplo, que precisam ser identificados e colocados como objeto de conhecimento nos diálogos sobre o currículo. O estágio oferece esses e outros tantos desafios.

Neste texto, busquei apresentar algumas construções teóricas que constituem a pedagogia progressista de Paulo Freire, e que caracterizam a educação problematizadora desse pensador, extremamente importantes para as orientações e a organização didática dos estágios curriculares em docência, considerando que as crianças merecem um ensino crítico, instigador da curiosidade e da pesquisa, movido pela preocupação com a humanização e ética universal dos seres humanos, para que possamos contribuir com uma sociedade menos injusta e desigual.

\section{Algumas considerações}

Neste texto, busquei sistematizar alguns resultados da pesquisa intitulada Em busca de uma formação problematizadora e crítica durante os Estágios Curriculares Supervisionados: perspectivas a partir da práxis freiriana (2017-2020), vinculada ao Grupo de Estudos e Pesquisas sobre Educação em Espaços Escolares e Não Escolares, que coordeno na UEPG. Esta pesquisa buscou investigar contribuições das construções teóricas e da ação dialógica de Paulo Freire para a organização didática dos Estágios Curriculares Supervisionados nos cursos de Pedagogia, bem como sistematizar orientações e práticas para os estágios a partir da práxis problematizadora e crítica do autor. As construções teóricas destacadas neste artigo foram a pesquisa rigorosa, a curiosidade epistemológica, a dialogicidade, a solidariedade, a criticidade, a relação leitura de mundo e leitura da palavra, a humildade, a ética e a estética, e o compromisso político, apresentados em suas relações, como fundamentais para a organização didática dos estágios.

A didática do Estágio Curricular Supervisionado em docência é desenvolvida em diferentes momentos na UEPG, que acontecem por meio de discussões coletivas de concepções teóricopráticas na universidade, orientações coletivas para a realização da carga horária de observação,

Práxis Educativa, Ponta Grossa, v. 15, e2017067, p. 1-23, 2020

Disponível em: < https://www.revistas2.uepg.br/index.php/praxiseducativa> 
análise dos planejamentos construídos pelas estagiárias e pelos estagiários, orientações individuais sobre esses planejamentos, revisão dos planejamentos corrigidos, acompanhamento da carga horária de docência com cada estudante (51 horas), seminários de finalização dos estágios. Em cada etapa desse trabalho de orientação e acompanhamento dos estágios, tenho me guiado pelas construções teóricas de Paulo Freire, avaliando, a cada ano e com cada turma, os aspectos a serem mantidos e aqueles que precisam ser revistos.

A etapa de formação em que são realizados os estágios é definida pelas(os) estudantes como impactantes, pois precisam refletir e relacionar conhecimentos das áreas da Filosofia, da Psicologia, da Sociologia, da Política Educacional, da Didática, das Metodologias de Ensino, da Alfabetização, entre outras. Além disso, é a oportunidade que elas e eles têm de colocarem-se nas relações com as crianças, com a professora da sala, com a equipe gestora da escola, experimentando desafios, dilemas, satisfações, descobertas, espantos, questionamentos, decepções, surpresas, que chegam até mim, como professora orientadora, por meio dos registros escritos e durante o acompanhamento das docências. As e os estudantes mobilizam muitos saberes e buscam estratégias de trabalho em diferentes fontes, preocupadas(os) com a qualidade de suas aulas e com o envolvimento das(os) alunas(os), seguindo as orientações oferecidas, fundamentadas na educação problematizadora de Paulo Freire.

Entretanto, não passam por situações problemáticas sozinhas ou sozinhos. Do início ao final de suas aulas, as estagiárias e os estagiários podem contar com meu apoio respeitador e discreto, na forma de sugestões, correções e esclarecimentos oferecidos sem chamar atenção das crianças, mas permitindo que vejam duas profissionais se ajudando para que a aula seja muito boa, constatando a solidariedade e não a punição ou humilhação. Esse apoio dá-se no decorrer de toda a aula para que se sintam mais seguras(os) e se lembrem dos princípios progressistas que guiam suas ações:

- a humildade, quando ocorre um erro e precisa ser corrigido com o grupo de alunos;

- a abordagem crítica dos temas tratados, possibilitado pela pesquisa rigorosa;

- o desenvolvimento dos conteúdos partindo de perguntas e ações concretas;

- a ética relacionada a cada tipo de conhecimento trabalhado e seu uso social;

- a amorosidade e a solidariedade como princípios para as ações entre educador(a)educandos(as) e entre educandos(as);

- a participação igualitária de todas as crianças nas discussões de temas, para que elas possam vivenciar a importância do momento de fala e de escuta do outro;

- a valorização do saber de experiência feito e sua relação com o conhecimento científico;

- o exercício da coerência entre o que se fala e o que se faz.

Quando esses princípios, oriundos das construções teóricas de Paulo Freire, são esquecidos durante as docências, as estagiárias e os estagiários são alertadas(os) pela professora orientadora do estágio, que registra os pontos fortes da aula e aqueles que foram, porventura, esquecidos e resgatados no decorrer da aula. Essa forma de atuar como orientadora, colaborando para que as estagiárias e os estagiários conduzam melhor suas ações e possam corrigi-las durante as docências, parte da postura de que não faz sentido acompanhar as docências somente para avaliar. É preciso atuar como parceira experiente e sensível nesse momento que traz muita ansiedade e insegurança e provoca, muitas vezes, mal-estar físico nas estagiárias e nos estagiários. É preciso dialogar sobre como foi o desenvolvimento da aula, após seu término, considerando a colaboração estabelecida e o retorno das crianças às proposições feitas.

Enfim, a professora orientadora também deve testemunhar a coerência, a humildade, a amorosidade, a solidariedade, o rigor científico e ético de sua profissão de formadora, o 
A epistemologia de Paulo Freire na formação de pedagogas(os) durante os Estágios Curriculares...

compromisso político que assume com a formação de futuras professoras e de futuros professores progressistas, mesmo sem poder garantir que suas orientações sejam lembradas e mobilizadas após o ingresso na profissão. O estágio curricular sozinho, assim como a formação em sua totalidade, no curso de Pedagogia, não provoca as transformações que sonhamos, mas lança as sementes de uma outra educação possível dentro das escolas.

Os Estágios Curriculares Supervisionados e os cursos de Pedagogia precisam ser repensados continuamente, para que possam contribuir para a formação de uma ordem social democrática nas escolas e em seu entorno. No entanto, os processos de transformação autêntica ocorrerão somente com o envolvimento de todas as pessoas que educam - universidade, escolas e comunidades - no contexto das ações de ensino, pesquisa e extensão.

\section{Referências}

ANDREOLA. B. A. Pedagogia do oprimido: um projeto coletivo. In: FREIRE, A. M. A. (org.). A pedagogia da libertação em Paulo Freire. São Paulo: Editora UNESP, 2001. p. 43-46.

ANPED. Associação Nacional de Pós-Graduação e Pesquisa em Educação. Uma formação formatada. Posição da ANPED sobre o "Texto Referência - Diretrizes Curriculares Nacionais e Base Nacional Comum para a Formação Inicial e Continuada de Professores da Educação Básica". 2019. Disponível em: https://anped.org.br/news/posicao-da-anped-sobre-texto-referencia-dcne-bncc-para-formacao-inicial-e-continuada-de. Acesso em: 12 dez. 2019.

AROEIRA, K. P. Estágio supervisionado possibilidades para uma formação com vínculos colaborativos entre a universidade e a escola. In: ALMEIDA, M. I. de; PIMENTA, S. G. (org.). Estágios supervisionados na formação docente. São Paulo: Cortez, 2014. p. 113-151.

ARROYO, M. G. Paulo Freire em tempos de exclusão. In: FREIRE, A. M. A. (org.). A Pedagogia da Libertação em Paulo Freire. São Paulo: Editora UNESP, 2001. p. 163-170.

BOGDAN, R.; BIKLEN, S. Investigação qualitativa em Educação: uma introdução à teoria e aos métodos. Porto: Porto Editora, 1994.

BRAGA, F. M.; GABASSA, V.; MELLO, R. R. de. Aprendizagem dialógica: ações e reflexões de uma prática educativa de êxito. São Carlos: EdUFSCar, 2010.

BRANDÃO, A.. 5\% mais ricos do Brasil detêm a mesma renda que os outros $95 \%$. Observatório do Terceiro Setor, 27 set. 2018. Disponível em: https://observatorio3setor.org.br/noticias/5mais-ricos-da-populacao-faturam-por-mes-o-mesmo-que-os-95/. Acesso em: 30 maio 2020.

BRASIL. Resolução CNE/CP N ${ }^{\circ}$ 2, de 1 de julho de 2015. Define as Diretrizes Curriculares Nacionais para a formação inicial em nível superior (cursos de licenciatura, cursos de formação pedagógica para graduados e cursos de segunda licenciatura) e para a formação continuada. Diário Oficial da União: seção 1, Brasília, DF, n. 124, p. 8-12, 2 jul. 2015.

BRASIL. Resolução CNE/CP N $\mathrm{N}^{\circ}$ 2, de 20 de dezembro de 2019. Define as Diretrizes Curriculares Nacionais para a Formação Inicial de Professores para a Educação Básica e institui a Base Nacional Comum para a Formação Inicial de Professores da Educação Básica (BNCFormação). Brasília: Conselho Nacional de Educação; Conselho Pleno, [2019]. Disponível em: http://portal.mec.gov.br/docman/dezembro-2019-pdf/135951-rcp002-19/file. Acesso em: 20 jun. 2020. 
BRASIL. Relatório SAEB/ANA 2016: panorama do Brasil e dos estados. Brasília: Instituto Nacional de Estudos e Pesquisas Educacionais Anísio Teixeira, 2018.

CRESWELL, J. W. Projeto de pesquisa: métodos qualitativo, quantitativo e misto. Porto Alegre: Artmed, 2010.

DAMBROSKI, C. A importância do estágio curricular supervisionado para a formação docente no curso de Pedagogia da Universidade Estadual de Ponta Grossa. 2016. Trabalho de Conclusão de Curso (Graduação em Pedagogia) - Universidade Estadual de Ponta Grossa, Ponta Grossa, Paraná.

FIORI, E. M. Aprender a dizer a sua palavra. In: FREIRE, P. Pedagogia do oprimido. Rio de Janeiro: Paz e Terra, 2004. p. 9-21.

FLECHA, R. Por que Paulo Freire é o principal pedagogo na atual sociedade da informação? In: FREIRE, A. M. A. (org.). A pedagogia da libertação em Paulo Freire. São Paulo: Editora UNESP, 2001. p. 203-206.

FREIRE, A. M. A. Paulo Freire: uma história de vida. Indaiatuba, SP: Villa das Letras, 2006.

FREIRE, P. À sombra desta mangueira. São Paulo: Editora Olho d'Água, 2005.

FREIRE, P. Pedagogia da autonomia: saberes necessários à prática educativa. Rio de Janeiro: Paz e Terra, 2014.

FREIRE, P. Pedagogia da esperança: um encontro com a pedagogia do oprimido. Rio de Janeiro: Paz e Terra, 2003.

FREIRE, P. Pedagogia da indignação. São Paulo: Editora UNESP, 2000.

FREIRE, P. Pedagogia do compromisso: América Latina e educação popular. Indaiatuba, São Paulo: Villa das Letras, 2008.

FREIRE, P. Pedagogia do oprimido. Rio de Janeiro: Paz e Terra, 2004.

FREIRE, P.; SHOR, I. Medo e ousadia: o cotidiano do professor. Rio de Janeiro: Paz e Terra, 2003.

FREITAS, H. C. L. de. CNE ignora entidades da área e aprova Parecer e Resolução sobre BNC da Formação. Educar Mais, Pelotas, v. 4, n. 1, p. 1-3, 2020. DOI: https://doi.org/10.15536/reducarmais.4.2020.1-3.1711

GABRIEL, F. A.; PEREIRA, A. L.; JESUZ, D. A. F. de. Estágio Supervisionado nas Licenciaturas: o estado do conhecimento com base nas dissertações e teses de instituições brasileiras. Revista Pedagógica, Chapecó, v. 20, n. 45, p. 227-247, set./dez. 2018. DOI: https://doi.org/10.20396/zet.v25i1.8647637

GATTI, B. A.; BARRETO, E. S. S.; ANDRÉ, M. E. D. A. de; ALMEIDA, P. C. A. Professores do Brasil: novos cenários de formação. Brasília: UNESCO, 2019.

JACOMINI, M. A.; PENNA, M. G. de. Carreira docente e valorização do magistério: condições de trabalho e desenvolvimento profissional. Pro-Posições, Campinas, v. 27, n. 2, p. 177-202, maio/ago. 2016. DOI: https://doi.org/10.1590/1980-6248-2015-0022 
A epistemologia de Paulo Freire na formação de pedagogas(os) durante os Estágios Curriculares...

LIMA, T. C. S. de.; MIOTO, R. C. T. Procedimentos Metodológicos na construção do conhecimento científico: a pesquisa bibliográfica. Revista Katálysis, Florianópolis, v. 10, n. esp. p. 37-45, 2007. DOI: https://doi.org/10.1590/S1414-49802007000300004

LÜDKE, H. A.; ANDRÉ, M. E. D. A. de. Pesquisa em Educação: abordagens qualitativas. São Paulo: EPU, 1986.

MARCONI, M. A.; LAKATOS, E. M. Fundamentos de metodologia científica. São Paulo: Atlas, 2003.

MELLO, R. R. de.; BRAGA, F. M.; GABASSA, V. Comunidades de aprendizagem: outra escola é possível. São Carlos: EdUFSCar, 2012.

NASCIMENTO, A. M. do. O Estágio Curricular Supervisionado no Curso de Pedagogia: diálogo entre universidade e escola à luz de Paulo Freire. 2014. Dissertação (Mestrado em Educação: Formação de Professores) - Universidade Estadual do Ceará, Fortaleza, 2014.

OLIVEIRA, H. L. G.; LEIRO, A. C. R. Políticas de Formação de Professores no Brasil: referenciais legais em foco. Pro-Posições, Campinas, v. 30, e20170086, p. 1-26, abr. 2019. DOI: https://doi.org/10.1590/1980-6248-2017-0086

OPAS. Organização Pan-Americana da Saúde. Folha informativa - COVID-19 (doença causada pelo novo coronavírus). Organização Pan-Americana da Saúde, 29 jun. 2020. Disponível em: https:/ / www.paho.org/bra/index.php?option=com_content\&view=article\&id=6101:covid19\&I temid=875. Acesso em: 29 jun. 2020.

PAULA, L. C. de. Contribuições da práxis histórica de Paulo Freire às pesquisas e propostas sobre educação contínua de educadores(as). 2011. Tese (Doutorado em Educação) - Centro de Educação e Ciências Humanas, Universidade Federal de São Carlos, São Carlos, 2011.

PEREIRA, A. L. N. O estágio curricular supervisionado em espaços não escolares no curso de pedagogia da Universidade do Estado da Bahia (UNEB): as contribuições no percurso formativo. 2017. Tese (Doutorado em Educação: Currículo) - Pontifícia Universidade Católica de São Paulo, São Paulo, 2017.

PIMENTA, S. G.; LIMA, M. S. L. Estágio e docência. São Paulo: Cortez, 2011.

SALVADOR, A. D. Métodos e técnicas de pesquisa bibliográfica. Porto Alegre: Sulina, 1986.

SANTIAGO, M. E. A prática pedagógica na universidade com base na Pedagogia Freireana: relato de uma experiência. In: SAUL, A. M. (org.). Paulo Freire e a formação de educadores: múltiplos olhares. SP: Editora Articulação Universidade/Escola, 2004. p. 126-140.

SAUL, A. M.; SAUL, A. Contribuições de Paulo Freire para a formação de educadores: fundamentos e práticas de um paradigma contra-hegemônico. Educar em Revista, Curitiba, n. 61, p. 19-35, jul./set. 2016. DOI: https://doi.org/10.1590/0104-4060.46865

SEVERINO, A. J. Metodologia do trabalho científico. São Paulo: Cortez, 2007.

SILVA, I. de B. S. O estágio curricular supervisionado em docência na Educação Infantil sob o olhar das(os) acadêmicas(os) de Pedagogia da UEPG, das educadoras de um CMEI de Ponta Grossa e das professoras orientadoras de estágio da UEPG. 2016. Trabalho de Conclusão de Curso (Graduação em Pedagogia) - Universidade Estadual de Ponta Grossa, Ponta Grossa, Paraná. 
TRIVIÑOS, A. N. S. Introdução à pesquisa em Ciências Sociais: a pesquisa qualitativa em educação. São Paulo: Atlas, 1987.

VOSGERAU, D. S. R.; ROMANOWSKI, J. P. Estudos de Revisão: implicações conceituais e metodológicas. Diálogo Educacional, Curitiba, v. 14, n. 41, p. 165-189, jan./abr. 2014. DOI: http://dx.doi.org/10.7213/dialogo.educ.14.041.DS08

ZITKOSKI, J. J. Dialética. In: STRECK, D. R.; REDI, E.; ZITKOSKI, J. J. (org.). Dicionário Paulo Freire. Belo Horizonte: Autêntica Editora, 2008. p. 127-130.

Recebido em 12/09/2020

Aceito em 26/10/2020

Publicado online em 09/11/2020 